\title{
MAKNA SIMBOLIK TRADISI REBO KASAN
}

\author{
Rian Rahmawati ${ }^{1}$, Zikri Fachrul Nurhadi², Novie Susanti Suseno ${ }^{3}$ \\ ${ }^{1,2,3}$ Fakultas Ilmu Komunikasi, Konsentrasi Public Relations, Universitas Garut \\ Jl.Raya Samarang No 52A Tarogong Kidul, Garut, 44151 \\ No. HP: ${ }^{1} 081221858891,{ }^{2} 085353325544,{ }^{3} 082240975440$ \\ E-mail: ${ }^{1}$ rianrahmawati93@gmail.com, ${ }^{2}$ kiky_81@yahoo.co.id, ${ }^{3}$ novie_ss@yahoo.com
}

Naskah diterima tanggal 31 Desember 2016, direvisi tanggal 2 Maret 2017, disetujui tanggal 19 April 2017

\section{THE SYMBOLIC MEANING OF TRADITION REBO KASAN}

\begin{abstract}
This research is especially backgrounded by the interested in relating to the meaning inside using the symbol in Rebo Kasan tradition which exists in some societies in Garut. This circumstance is very important, considering that Rebo Kasan is one of the history which contains the moral value and religion within. The aims of this research are to find out and explain in depth concerning the meaning of denotative, connotative and myth towards the symbol Of Rebo Kasan in Garut. The method used in this research is the analysis method of Roland Barthes' semiotics. This research investigates the signals either in the meaning of denotation, connotation or myth by using a qualitative approach. This research expresses the meaning of denotation, connotation and myth towards the symbol which is used in Rebo Kasan tradition in Garut. Whereas, the technique of data sampling used in this research is participatory observation, in depth interview, and literature review. Subjects in this study are the dishes that was served at the celebration of the tradition. Besides, the informants that chosen for this research is five people from society that involved in this tradition. This study found that Rebo Kasan has the meaning of denotation, connotation and myth. The traditional food of Rebo Kasan is one of the charity which is intended to reject and hold the danger. While dupi as the symbol of rejection, leupeut as the symbol of unity and bugis as the symbol of belief.

Keywords: value, symbolic, tradition of Rebo Kasan, Semiotic of Roland Bhartes.
\end{abstract}

\begin{abstract}
Abstrak. Penelitian ini dilatarbelakangi oleh ketertarikan peneliti terkait makna di balik penggunaan simbol tertentu pada tradisi Rebo Kasan yang sampai sekarang masih dipertahankan oleh beberapa kelompok masyarakat di Kabupaten Garut. Tujuan penelitian ini adalah untuk menemukan dan menjelaskan lebih dalam mengenai makna denotasi, konotasi, dan mitos pada simbol-simbol Rebo Kasan di Kabupaten Garut. Metode penelitian yang digunakan dalam penelitian ini adalah metode analisis Semiotik Roland Barthes. Penelitian ini mengungkap makna denotasi, konotasi, dan mitos pada simbol-simbol yang digunakan dalam tradisi Rebo Kasan di Kabupaten Garut. Sedangkan teknik pengumpulan data yang digunakan adalah observasi partisipan, wawancara mendalam, dan studi kepustakaan. Subjek pada penelitian ini adalah jamuan yang dihidangkan pada perayaan tradisi tersebut serta pengambilan informan dengan menggunakan purposive sampling. Jumlah informan dalam penelitian ini adalah sebanyak lima orang. Hasil penelitian menunjukkan bahwa dalam tradisi Rebo Kasan di Kabupaten Garut memiliki makna denotasi, konotasi, dan mitos. Adapun yang merupakan simbol tradisi tersebut adalah, air putih, dupi, leupeut, dan bugis, yang merupakan makanan khas dari daerah tersebut. Makna tradisi dari Rebo Kasan itu sendiri adalah berbagi atau bersedekah dengan tujuan menolak marabahaya yaitu dengan jamuan berupa makanan
\end{abstract}


yang dimaknai dengan makna tertentu yaitu di antaranya, air putih merupakan simbol kesucian, dupi sebagai simbol penolakan, leupeut sebagai simbol mempersatukan, dan bugis sebagai simbol keyakinan.

Kata Kunci: makna, simbolik, tradisi Rebo Kasan, Semiotik Roland Barthes.

\section{PENDAHULUAN}

Tanah Sunda (Priangan) dikenal memiliki aneka budaya yang unik dan menarik. Sunda sebagai salah satu suku dengan tradisi yang istimewa. Selain itu suku Sunda terkenal pula sebagai masyarakat yang religious atau agamis. Hal ini, tampak pada beberapa ritual keagamaan yang sering dilakukan oleh suku Sunda yang berlandaskan pada kepercayaan yang mereka anut. Salah satunya tradisi yang saat ini masih dilakukan oleh sebagian kecil orang Sunda khususnya pada masyarakat Garut adalah tradisi Rebo Kasan. Tradisi Rebo Kasan ini sebetulnya merupakan tradisi yang diadopsi dari suku Jawa, sebagai buktinya tradisi ini masih terus dilakukan oleh sebagian besar orang Jawa, seperti di Yogyakarta, Bangka Belitung, dan daerah lainnya. Garut merupakan salah satu daerah yang sebagian besar masyarakatnya masih melakukan tradisi Rebo Kasan terutama di daerah terpencil atau perdesaan. Meskipun tidak semua masyarakat melakukan tradisi ini bahkan sebagian tidak mengenal tradisi ini karena berbagai pendapat yang pro dan kontra terhadap tradisi tersebut yang dianggap tidak sesuai dengan ajaran agama atau melenceng dari sudut pandang agama Islam. Hal ini, disebabkan karena adanya konfrontasi (bukan hubungan saling mengisi dan membangun) antara agama dan praktik budaya, adalah salah satu penyebabnya. Meskipun begitu bagi mereka yang melakukannya, tetap mempertahankan tradisi tersebut asal tetap dimaksudkan untuk berdoa kepada Allah SWT berdasarkan kepercayaan dan pemahaman yang mereka pegang meskipun disimbolkan dengan sesuatu yang berbeda berkaitan dengan budaya yang selama ini berkembang berdasarkan tradisinya.

Tradisi Rebo Kasan adalah suatu tradisi di mana suatu kelompok masyarakat berkumpul dan berdoa dengan maksud menolak beribu-ribu marabahaya yang konon turun pada hari terakhir di Bulan Safar. Rebo Kasan berasal dari bahasa Jawa yaitu Rebo Wekasan yang artinya hari Rabu terakhir atau penghabisan pada Bulan Safar, yang menurutnya merupakan hari diturunkannya 320.000 bala atau marabahaya ke muka bumi (Saripudin, 2010). Secara umum, tradisi Rebo Kasan dilakukan sebagian umat Islam yaitu Rebo Wekasan (Jawa) atau Rabu Pungkasan (Yogyakarta) atau Rebo Kasan (Sunda Banten) dengan berbagai cara (Rosidi, Ajip dan Chaedar, 2006).

Berdasarkan hasil pengamatan yang dilakukan sebagian masyarakat Garut, maka Rebo Kasan dilakukan dengan cara melakukan: (a) persiapan, artinya sebelum tradisi dimulai biasanya sudah mempersiapkan air dalam teko atau kompan serta berbagai makanan yang kemudian akan mereka simpan di masjid untuk didoakan. Setelah itu tepat setelah salat subuh para ibu memulai tradisi dengan saling berbagi makanan sedangkan para bapak dan anak laki-laki bersiap ke masjid. Sebelum pukul 06.00 WIB marbot masjid mengumumkan kepada para bapak untuk segera ke masjid karena perayaan Rebo Kasan akan segera dimulai; (b) pembukaan, setelah tepat pukul 06.00 WIB para bapak dan anak laki-laki sudah berkumpul di masjid untuk mengikuti perayaan Rebo Kasan yang dipimpin oleh seorang ustaz di sana. Pembukaan perayaan dimulai dengan memberikan pengarahan atau dakwah singkat sekitar tujuh menit mengenai asal mulai tradisi Rebo Kasan, 
tujuan perayaan Rebo Kasan, sampai pada bagaimana pelaksanaan salat Tolak Bala. Hal ini, penting untuk dijelaskan sebelumnya, karena tradisi ini merupakan tradisi tahunan dan dikhawatirkan para bapak lupa dan bahkan ada peserta tradisi yang baru pertama kali mengikuti perayaan tersebut; (c) Salat Tolak Bala, setelah pembukaan, barulah para bapak melaksanakan salat Tolak Bala tanpa berjamaah, yaitu sebanyak dua rakaat, yang dalam setiap rakaatnya membaca Surat AlFatihah sekali, Surat Al-Kautsar 15 kali, Surat Al-Ikhlas lima kali, Surat Al-Falaq sekali, Surat An-Nass sekali; (d) Pembacaan Doa dan selawat, selanjutnya dalam perayaan Rebo Kasan para bapak melaksanakan beberapa runtutan doa, mulai dari pembacaan surat Al-Fatihah, Surat Al-Falaq, surat Al-Ikhlas, doa untuk yang telah meninggal dunia (tawasul) atau disebut juga pemberian hadiah, dan selawat Nabi; (e) Penutup, setelah berbagai ritual mereka lakukan selanjutnya pemimpin perayaan yaitu seorang ustaz menutup perayaan tersebut dengan doa dan pengharapan yang baik di hari itu.

Terkait dengan cara-cara yang dilakukan pada tradisi Rebo Kasan ini, maka peneliti menganalisis ada beberapa hal yang menjadi acuan atau tolak ukur untuk menjadi bahan kajian terkait dengan makna tradisi Rebo Kasan melalui teori Semiotika Roland Barthes dilihat dari segi makna denotasi, konotasi, dan mitos. Peneliti melihat terdapat unsur-unsur yang memiliki hubungan di antara bagaimana sebagian masyarakat Garut melakukan komunikasi ritual melalui berbagai penanda dan pertanda yang digolongkan ke dalam tatanan makna tradisi Rebo Kasan, di antaranya sebagai penanda denotasi meliputi: Rebo Kasan, air putih, dupi, leupeut, bugis yang masing-masing memiliki petanda dan makna yang berbeda. Begitupun pada penanda konotasi meliputi: Rebo Kasan, air putih, dupi, leupeut, bugis, yang memiliki unsur makna konotasi petanda yang berbeda dengan makna denotasi. Tak kalah pentingnya penanda pada mitos juga meliputi: Rebo Kasan, air putih, dupi, leupeut, bugis yang memiliki makna yang berbeda dengan unsur lainnya.

Dalam tradisi Rebo Kasan tersebut ada tindakan yang sifatnya sakral. Tindakan religious seluruhnya bersifat simbolis, sehingga dalam tindakan ini digunakan simbol khas yang mewakilinya (Budiman, 2008). Di mana simbol-simbol tersebut mempunyai fungsi, peranan, dan makna tersendiri. Simbol-simbol yang digunakan dalam tradisi ini berbeda tiap daerahnya, kalau di Sunda disimbolkan dengan simbol non verbal yaitu dengan leupeut dan sejenisnya sedangkan kalau dalam adat Jawa disimbolkan dengan ketupat bahkan proses tradisinya pun dilakukan dengan berbeda sesuai dengan caranya masing-masing. Semua makna budaya diciptakan dengan menggunakan simbol-simbol, makna hanya dapat disimpan di dalam simbol. Pengetahuan kebudayaan lebih dari suatu kumpulan simbol, baik istilah-istilah rakyat maupun jenis-jenis simbol lain. Semua simbol, baik kata-kata yang terucapkan, sebuah objek seperti sebuah bendera, suatu gerak tubuh seperti melambaikan tangan, sebuah tempat seperti masjid atau gereja, atau suatu peristiwa seperti perkawinan, merupakan bagian-bagian suatu sistem simbol. Simbol adalah objek atau peristiwa apapun yang menunjuk pada sesuatu. Simbol itu meliputi apa yang dapat dirasakan atau dialami (Sobur, 2013).

Dalam hal ini, agama memengaruhi sistem kepercayaan serta praktik-praktik kehidupan. Sebaliknya kebudayaan pun dapat memengaruhi agama, khususnya dalam hal bagaimana agama diinterpretasikan/ bagaimana ritualritualnya harus dipraktikkan. Tidak ada agama yang bebas budaya dan apa yang disebut Sang Illahi tidak akan mendapatkan makna manusiawi yang tegas tanpa mediasi budaya, dalam masyarakat Indonesia saling memengaruhi antara agama dan kebudayaan sangat terasa. Praktik inkulturasi dalam upacara keagamaan hampir umum dalam semua agama. 
Berdasarkan penjelasan yang telah dipaparkan, maka peneliti tertarik untuk melakukan penelitian dengan judul: "Makna Simbolik Tradisi Rebo Kasan di Kabupaten Garut". Adapun tujuan penelitian ini adalah untuk menemukan dan menjelaskan makna denotasi, konotasi, dan mitos simbolik tradisi Rebo Kasan serta dapat memberikan manfaat pengetahuan kepada masyarakat khususnya di Kabupaten Garut mengenai tradisi Rebo Kasan sebagai bentuk nyata bagi masyarakat Sunda yang bangga akan kekayaan budaya Sunda, serta dapat memberikan pemahaman tentang arti budaya secara lebih kompleks khususnya tradisi Rebo Kasan yang dapat mewarnai kajian penelitian baik secara nyata maupun secara keilmuan teoretis.

\section{LANDASAN KONSEP}

Sejumlah penelitian tentang makna simbolik tradisi Rebo Kasan khususnya di Kabupaten Garut belum banyak dilakukan. Hal ini, dimaksudkan untuk memberikan bahan perbandingan dan referensi agar makna simbolik tradisi Rebo Kasan dapat dipahami, sehingga penelitian ini mampu menyajikan hasil penelitian yang memiliki nilai originalitas. Adapun penelitianpenelitian sebelumnya yang relevan dengan masalah yang diteliti dapat dilihat dalam tabel 1, yaitu:

Tabel 1

Perbedaan Penelitian Makna Simbolik Tradisi Rebo Kasan dengan Penelitian Terdahulu

\begin{tabular}{|c|c|c|c|}
\hline & Komunikasi Ritual & Makna Pesan Upacara & Makna Simbolik Tradisi \\
\hline & $\begin{array}{l}\text { Ruwatan Kampung di } \\
\text { Desa Bunihayu Kabupaten } \\
\text { Subang }\end{array}$ & $\begin{array}{l}\text { Sawer Pada Pernikahan } \\
\text { Adat Sunda Kabupaten } \\
\text { Garut }\end{array}$ & $\begin{array}{l}\text { Rebo Kasan Kabupaten } \\
\text { Garut }\end{array}$ \\
\hline Penulis & $\begin{array}{l}\text { Jumiaty (2013). Jurnal } \\
\text { Komunikasi, Fakultas } \\
\text { Ilmu Sosial dan Politik, } \\
\text { Universitas Hasanuddin } \\
\text { Makassar }\end{array}$ & $\begin{array}{lr}\text { Evi } & \text { Komalasari } \\
\text { Jurnal } & \text { Komunikasi, } \\
\text { Fakultas } & \text { Ilmu } \\
\text { Komunikasi } & \text { Universitas } \\
\text { Garut } & \end{array}$ & $\begin{array}{l}\text { Rian Rahmawati, Zikri } \\
\text { Fachrul Nurhadi, Novie } \\
\text { Susanti Suseno }\end{array}$ \\
\hline $\begin{array}{l}\text { Deskripsi } \\
\text { Penelitian }\end{array}$ & $\begin{array}{l}\text { Deskripsi penelitian ini } \\
\text { berfokus pada makna } \\
\text { simbolik yang terkandung } \\
\text { dalam tradisi To } \\
\text { Ma'badong adalah makna } \\
\text { saling mengasihi, } \\
\text { menghormati, menjunjung } \\
\text { serta mengingat jasa-jasa } \\
\text { leluhur. Penelitian ini juga } \\
\text { melihat adanya pesan- } \\
\text { pesan simbolik yang } \\
\text { terkandung dalam tradisi } \\
\text { To Ma'badong di mana } \\
\text { jika tetap melaksanakan } \\
\text { tradisi ini leluhur akan } \\
\text { senantiasa memberikan } \\
\text { kesejahteraan, melindungi } \\
\text { dan mengaruniakan rezeki } \\
\text { yang lapang bagi } \\
\text { keturunannya. }\end{array}$ & $\begin{array}{l}\text { Deskripsi penelitian ini } \\
\text { berfokus pada } \\
\text { permasalahan makna } \\
\text { denotasi, konotasi, dan } \\
\text { mitos upacara sawer } \\
\text { pernikahan adat Sunda } \\
\text { khususnya di Kabupaten } \\
\text { Garut. }\end{array}$ & $\begin{array}{lr}\text { Deskripsi penelitian ini } \\
\text { menitikberatkan kepada } \\
\text { ketertarikan peneliti terkait } \\
\text { makna di balik penggunaan } \\
\text { simbol tertentu pada tradisi } \\
\text { Rebo Kasan yang sampai } \\
\text { sekarang } & \text { masih } \\
\text { dipertahankan } & \text { oleh } \\
\text { beberapa } & \text { kelompok } \\
\text { masyarakat di } & \text { Kabupaten } \\
\text { Garut. } & \end{array}$ \\
\hline
\end{tabular}




\begin{tabular}{|c|c|c|c|}
\hline $\begin{array}{c}\text { Fokus } \\
\text { Penelitian }\end{array}$ & $\begin{array}{l}\text { Fokus penelitian ini } \\
\text { kepada makna dan pesan- } \\
\text { pesan yang terkandung } \\
\text { pada tradisi } \\
\text { Ma'badong }\end{array}$ & $\begin{array}{l}\text { Fokus penelitian ini } \\
\text { mengenai prosesi upacara } \\
\text { Sawer pernikahan adat } \\
\text { Sunda di Kabupaten } \\
\text { Garut bahwa Sawer } \\
\text { memiliki makna yang ada } \\
\text { di dalam bahan-bahan } \\
\text { atau alat-alat yang } \\
\text { digunakan dalam prosesi } \\
\text { Sawer (beras, koneng, } \\
\text { uang receh, premen, dan } \\
\text { kanjut kudang, payung } \\
\text { dan bokor) itu semua } \\
\text { memiliki banyak sekali } \\
\text { arti dari simbol yang } \\
\text { terdapat dalam tradisi } \\
\text { pernikahan adat Sunda } \\
\text { ini. }\end{array}$ & $\begin{array}{l}\text { Fokus penelitian ini adalah } \\
\text { bagaimana makna simbolik } \\
\text { tradisi Rebo Kasan di } \\
\text { Kabupaten Garut. }\end{array}$ \\
\hline $\begin{array}{c}\text { Tujuan } \\
\text { Penelitian }\end{array}$ & $\begin{array}{l}\text { Untuk mengetahui apa } \\
\text { makna simbolik yang } \\
\text { terdapat dalam tradisi To } \\
\text { Ma'badong dalam upacara } \\
\text { Rambu Solo' di Tana } \\
\text { Toraja, mengetahui pesan- } \\
\text { pesan simbolik apa saja } \\
\text { yang terdapat dalam } \\
\text { tradisi To Ma'badong } \\
\text { dalam upacara Rambu } \\
\text { Solo. }\end{array}$ & $\begin{array}{l}\text { Untuk mengetahui (1) } \\
\text { pesan denotasi pada } \\
\text { upacara } \\
\text { pernikahan adat Sawer } \\
\text { Kabupaten Garut (2) } \\
\text { Pesan konotasi pada } \\
\text { upacara } \\
\text { pernikahan adat Sunda } \\
\text { Kabupaten Garut (3) } \\
\text { Mitos pada upacara } \\
\text { sawer pernikahan adat } \\
\text { Sunda Kabupaten Garut. }\end{array}$ & $\begin{array}{l}\text { Untuk menemukan dan } \\
\text { menjelaskan lebih dalam } \\
\text { mengenai makna denotasi, } \\
\text { konotasi, dan mitos pada } \\
\text { simbol-simbol Rebo Kasan } \\
\text { di Kabupaten Garut. }\end{array}$ \\
\hline $\begin{array}{l}\text { Pendekatan } \\
\text { Penelitian }\end{array}$ & $\begin{array}{l}\text { Kualitatif, } \\
\text { Komunikasi }\end{array}$ & $\begin{array}{l}\text { Kualitatif, teori analisis } \\
\text { semiotik }\end{array}$ & Kualitatif \\
\hline $\begin{array}{c}\text { Teknik } \\
\text { Pengumpulan } \\
\text { Data }\end{array}$ & $\begin{array}{l}\text { Wawancara mendalam, } \\
\text { observasi partisipan, studi } \\
\text { pustaka dan studi } \\
\text { dokumentasi dari berbagai } \\
\text { sumber. }\end{array}$ & $\begin{array}{l}\text { Wawancara mendalam, } \\
\text { observasi partisipan, } \\
\text { studi pustaka, dan studi } \\
\text { dokumentasi. }\end{array}$ & $\begin{array}{l}\text { Wawancara mendalam } \\
\text { dengan para informan, } \\
\text { observasi partisipatif, studi } \\
\text { pustaka, dan studi } \\
\text { dokumentasi. }\end{array}$ \\
\hline
\end{tabular}

\begin{tabular}{clr}
\hline $\begin{array}{c}\text { Perbedaan dan } \\
\text { Persamaan }\end{array}$ & Perbedaan & dengan \\
dengan & penelitian ini adalah dari \\
Penelitian & diteliti, permasalahan yang \\
Terdahulu & pendekatan & juga \\
& digunakan & yang \\
& penelitian. dalam \\
& persamaannya pada teori \\
& yang digunakan dan \\
& konteks & pedangkan \\
& difokuskan pada kajian \\
& budaya.
\end{tabular}

\section{Perbedaan dengan} penelitian ini adalah dari segi permasalahan yang diteliti. Sedangkan persamaannya pada teori dan pendekatan yang digunakan serta konteks penelitian difokuskan pada kajian budaya.
Perbedaan dengan penelitian ini adalah dari segi permasalahan yang diteliti. Sedangkan persamaannya pada teori dan pendekatan yang digunakan serta konteks penelitian difokuskan pada kajian makna denotasi, konotasi, dan mitos.

Sumber: diolah dari berbagai sumber 


\section{Teori Semiotika Roland Barthes}

Semiotika adalah suatu ilmu atau metode analisis untuk mengkaji tanda. Tanda-tanda adalah perangkat yang dipakai dalam upaya berusaha mencari jalan di dunia ini, di tengah-tengah manusia dan bersama-sama manusia (Hoed, 2011). Suatu tanda menandakan sesuatu selain dirinya sendiri dan makna (meaning) ialah hubungan antara suatu objek atau ide suatu tanda.

Konsep dasar ini mengikat bersama seperangkat teori yang amat luas berurusan dengan simbol, bahasa, wacana, dan bentuk-bentuk non verbal, teori-teori yang menjelaskan bagaimana tanda berhubungan dengan maknanya dan bagaimana tanda disusun. Secara umum, studi tentang tanda merujuk kepada semiotika Littlejohn (Sobur, 2009).

Menurut Lechte dalam (Sobur, 2009) adalah teori tentang tanda dan penandaan. Lebih jelas lagi semiotika menurut Serger dalam (Sobur, 2009) adalah suatu disiplin yang menyelediki semua bentuk komunikasi yang terjadi dengan sarana signs "tanda-tanda" dan berdasarkan pada sign system (code) "sistem tanda". Semiotika memiliki tiga bidang studi utama, yaitu :

1. Tanda itu sendiri. Hal ini terdiri atas studi tentang berbagai tanda yang berbeda, cara tanda-tanda yang berbeda itu dalam menyampaikan makna, dan cara tanda-tanda itu terkait dengan manusia yang menggunakannya. Tanda adalah kontruksi manusia dan hanya bisa dipahami dalam artian manusia yang menggunakannya.

2. Kode atau sistem yang mengorganisasikan tanda. Studi ini mencakup cara berbagai kode dikembangkan guna memenuhi kebutuhan suatu masyarakat atau budaya atau untuk mengeksploitasi saluran komunikasi yang tersedia untuk mentransmisikannya.

3. Kebudayaan tempat kode dan tanda bekerja. Ini pada gilirannya bergantung pada penggunaan kode-kode dan tanda-tanda itu untuk keberadaan dan bentuknya sendiri (Vera, 2014).

Menurut Barthes, semiology hendak mempelajari bagaimana kemanusiaan (humanity) memaknai hal-hal (things). Memaknai, dalam hal ini tidak dapat disamakan dengan mengomunikasikan. Memaknai berarti bahwa objek-objek tidak hanya membawa informasi, dalam hal mana objek-objek itu hendak berkomunikasi, tetapi juga mengonstitusi sistem terstruktur dari tanda (Sobur, 2009).

Barthes, dengan demikian melihat signifikansi sebagai sebuah proses yang total dengan suatu susunan yang sudah terstruktur.

Signifikansi tak terbatas pada bahasa, tetapi juga pada hal-hal lain di luar bahasa. Barthes menganggap kehidupan sosial sebagai sebuah signifikansi. Dengan kata lain, kehidupan sosial, apa pun bentuknya, merupakan suatu sistem tanda tersendiri (Kurniawan, 2001).

Selanjutnya Barthes menggunakan teori significant-signifier yang dikembangkan menjadi teori tentang metabahasa dan konotasi. Sebagaimana pandangan Saussure, Barthes juga meyakini bahwa hubungan antarpenanda dan pertanda tidak terbentuk secara almiah, melainkan bersifat arbiter. Bila Saussure hanya menekankan pada penandaan dalam tataran denotative, maka Roland Barthes menyempurnakan semiology Saussure dengan mengembangkan sistem penandaan pada tingkat konotatif.

Barthes juga melihat aspek lain dari penandaan, yaitu "mitos" yang menandai suatu masyarakat. Mitos muncul pada tataran konsep mental suatu tanda (Birowo, 2004).

Roland Barthes membuat sebuah model sistematis dalam menganalisis makna dari tanda-tanda fokus perhatian Barthes lebih tertuju kepada gagasan tentang signifikasi dua tahap (two order of signification) (Sobur, 2009). Signifikasi dua tahap ini terdiri dari 


\section{a. Denotasi}

Denotasi adalah tatanan pertandaan pertama landasan kerja Saussure. Tatanan ini menggambarkan relasi antara penanda dan petanda di dalam tanda, dan antara tanda dengan referennya dalam realitas eksternal. Barthes menyebut tatanan ini sebagai denotasi. Hal ini mengacu pada anggapan umum, makna jelaskan tentang tanda. Denotasi juga biasa disebut juga makna kamus dari sebuah kata atau terminologi atau objek ( literal meaning of a trem or object) (Kriyantono, 2009). Jika diucapkan sebuah kata yang mendenotasikan suatu hal tertentu maka itu berarti kata tersebut mau menunjukkan pada hal itu sendiri. Dengan pengertian tersebut dapat dikatakan bahwa kata 'ayam' mendenotasikan atau merupakan sejenis unggas tertentu yang memiliki ukuran tertentu, berbulu, berkotek, dan menghasilkan telur untuk sarapan kita (Sobur, 2013).

\section{b. Konotasi}

Konotasi adalah makna-makna kultural yang melekat pada sebuah terminologi (the cultural meanings that become attached to a term). Dalam istilah yang digunakan Barthes, konotasi dipakai untuk menjelaskan salah satu dari tiga cara kerja tanda dalam tatanan pertandaan kedua. Konotasi menggambarkan tatkala tanda bertemu dengan perasaan atau emosi penggunaannya dalam nilai-nilai kulturalnya. Ini terjadi tatkala makna bergerak menuju subjektif atau setidaknya intersubjektif. Ini terjadi tatkala interpretant dipengaruhi sama banyaknya penafsir dan objek atau tanda. Bagi Barthes, faktor penting dalam konotasi adalah penanda dalam tatanan pertama merupakan tanda konotasi (John Fiske, 2010). Ini sejalan dengan pendapat Arthur Asa Berger yang menyatakan bahwa kata konotasi melibatkan simbol-simbol, historis, dan hal-hal yang berhubungan dengan emosional. Kadang-kadang konotasi suatu kata sama bagi hampir setiap orang, kadang-kadang hanya berkaitan dengan pengalaman satu individu, atau lebih sering, dengan pengalaman sekelompok kecil individu tertentu Tubbs dan Moss (Sobur, 2013). Makna konotatif sebuah kata dipengaruhi dan ditentukan oleh dua lingkungan, yaitu lingkungan tekstual dan lingkungan budaya (Sumardjo, Jakob \& Saini, 1994). Lingkungan tekstual ialah semua kata di dalam paragraf dan karangan yang menentukan makna konotatif itu. Sebagai contoh sederhana dapat dikemukakan pengaruh tekstual terhadap kata 'kuda' sebagai berikut. Kalau kata 'kuda' diikuti dengan kata 'Arab', maka kata itu memiliki makna konotatif yang lain dibanding dengan kalau kata yang mengikutinya kata 'perunggu'. 'Kuda Arab' dan 'kuda perunggu' menjadi dua ungkapan (frase) yang mengandung makna konotatif lain, demikian pula kata-kata yang ada di dalamnya. Pengaruh lingkungan budaya menjadi jelas kalau diletakkan kata tertentu di dalam lingkungan budaya yang berbeda. Sebagai contoh, kata 'teratai' bagi umumnya bangsa Indonesia hanya akan mengungkapkan makna konotatif dengan keindahan belaka. Akan tetapi, di India bunga ini akan memiliki makna konotatif lain, karena baik dalam agama Hindu maupun agama Buddha, bunga teratai memiliki arti perlambangan (simbolik) yang dalam, yang berhubungan dengan kedua agama tersebut (Sobur, 2013).

\section{c. Mitos}

Barthes menggunakan mitos sebagai seorang yang percaya, dalam artian yang orisinal. Mitos adalah cerita yang digunakan suatu kebudayaan untuk memperjelas atau memahami beberapa aspek dari realitas atau alam. Bagi Barthes, mitos merupakan cara dari suatu kebudayaan tentang sesuatu, cara untuk mengonseptualisasikan atau memahami sesuatu. Barthes memikirkan mitos sebagai mata rantai dari konsep-konsep terkait. Bila konotasi merupakan pemaknaan tatanan kedua dari penanda, mitos merupakan pemaknaan tatanan kedua dari petanda 
(John Fiske, 2010). Aspek lain dari mitos yang ditekankan Barthes adalah dinamismenya. Seperti yang dinyatakan tadi, mitos berubah dan beberapa di antaranya dapat berubah dengan cepat guna memenuhi kebutuhan perubahan dan nilainilai kultural di mana mitos itu sendiri menjadi bagian dari kebudayaan tersebut (John Fiske, 2004).

\section{METODE PENELITIAN}

Penelitian ini menggunakan metode semiotika Rolands Barthes, yang mempelajari dan mengkaji hakikat tentang keberadaan suatu tanda. Tujuan analisis semiotik berupaya menemukan makna dan tanda termasuk hal-hal yang tersembunyi di balik sebuah tanda. Sebagai paradigma kritis, metode semiotika Rolands Barthes ini bersifat emik yang mendasarkan diri pada temuan-temuan yang diperantarai oleh nilai (dialogis dan dialektik). Sedangkan paradigma klasik lebih menekan kepada asumsi-asumsi yang sifatnya parametrik, angka-angka yang jauh sekali dengan penelitian dalam konteks budaya. Sementara paradigma konstruktivis mengasumsikan bahwa manusia secara aktif menginterpretasikan pengalamannya dari sudut pandang orang yang mengalaminya, atau dunia merupakan temuan-temuan yang diciptakan.

Karena sistem tanda sifatnya amat kontekstual dan bergantung pada pengguna tanda tersebut (Kriyantono, 2006). Fokus metode penelitian ini secara rinci bisa di lihat pada tabel 2.

Tabel 2

Fokus Metode Penelitian

\begin{tabular}{ll}
\hline \multicolumn{1}{c}{ Metode Penelitian } & \multicolumn{1}{c}{ Keterangan } \\
\hline Pendekatan Penelitian & $\begin{array}{l}\text { Pendekatan yang digunakan dalam penelitian ini adalah pendekatan kualitatif } \\
\text { atau juga disebut sebagai metode naturalistik dengan kondisi alamiah (natural } \\
\text { setting). }\end{array}$ \\
\hline Paradigma Penelitian & $\begin{array}{l}\text { Paradigma penelitian ini adalah kritis yang mengkaji pemahaman mengenai } \\
\text { makna denotasi, konotasi, dan mitos. }\end{array}$ \\
\hline Subjek Penelitian & $\begin{array}{l}\text { Subjek pada penelitian ini adalah orang-orang atau anggota yang telah } \\
\text { mengikuti tradisi tersebut >lima kali (anggota lama); sedangkan anggota baru } \\
\text { telah mengikuti tradisi Rebo Kasan <tiga kali, serta selain dua kategori } \\
\text { informan ada juga informan tambahan yaitu pemimpin tradisi Rebo Kasan, } \\
\text { yang tidak lain merupakan seorang ustaz yang berusia >45 tahun. }\end{array}$
\end{tabular}

\begin{tabular}{ll}
\hline Teknik Penentuan & Teknik penentuan informan ini dengan teknik purposive sampling yaitu \\
Informan & peneliti sudah menentukan sejumlah informan sesuai dengan tujuan yang \\
ingin diperoleh.
\end{tabular}

Pemilihan Informan $\quad$ Pemilihan informan didasarkan kepada informan yang mampu menggambarkan kembali fenomenanya yang telah dialaminya terutama dalam sifat alamiah dan maknanya, bersedia untuk terlibat dalam kegiatan penelitian yang membutuhkan waktu yang lama, serta bersedia untuk diwawancara dan direkam aktivitasnya selama wawancara atau selama penelitian berlangsung.

\begin{tabular}{ll}
\hline Teknik Pengumpulan & Teknik pengumpulan data yang digunakan adalah observasi partisipan, \\
Data & wawancara mendalam, dokumentasi, dan studi kepustakaan.
\end{tabular}

Sumber: Hasil penelitian berdasarkan data informan 


\section{HASIL PENELITIAN DAN PEMBAHASAN}

\section{Makna Denotasi Tradisi Rebo Kasan}

Denotasi adalah tatanan pertandaan pertama landasan kerja Saussure. Tatanan ini menggambarkan relasi antarpenanda dan petanda di dalam tanda, dan antara tanda dengan referennya dalam realitas eksternal. Berdasarkan hasil penelitian melalui wawancara yang dilakukan peneliti dengan beberapa informan, maka dapat diperoleh data seperti yang tertera dalam tabel 3 .

\section{Makna Konotasi Tradisi Rebo Kasan}

Konotasi menggambarkan tatkala tanda bertemu dengan perasaan atau emosi penggunaannya dalam nilai-nilai kulturalnya. Ini terjadi tatkala makna bergerak menuju subjektif atau setidaknya intersubjektif. Ini terjadi tatkala interpretant dipengaruhi sama banyaknya penafsir dan objek atau tanda. Berdasarkan hasil penelitian melalui wawancara yang dilakukan peneliti dengan beberapa informan, maka dapat diperoleh data seperti yang tertera dalam tabel 4 .

\section{Makna Mitos Tradisi Rebo Kasan}

Barthes menggunakan mitos sebagai seorang yang percaya, dalam artian yang orisinal. Mitos adalah cerita yang digunakan suatu kebudayaan untuk memperjelas atau memahami beberapa aspek dari realitas atau alam. Berdasarkan hasil penelitian melalui wawancara yang dilakukan peneliti dengan beberapa informan, maka dapat diperoleh data seperti yang tertera dalam tabel 5 .

\section{Pembahasan}

Pada bagian ini, penulis akan menguraikan pembahasan terkait dengan makna simbolik tradisi Rebo Kasan yang dilihat dari makna denotasi, konotasi, dan mitos. Pembahasan juga merupakan interpretasi peneliti tentang hasil penelitian dengan analisis terkait teori dan konsep yang telah dikaji.

Tabel 3

Makna Denotasi Tradisi Rebo Kasan

\begin{tabular}{|c|c|}
\hline Penanda & Petanda \\
\hline Rebo Kasan & $\begin{array}{l}\text { Rebo panutup dina Bulan Sapar (Hari Rabu terakhir di Bulan } \\
\text { Shafar ) }\end{array}$ \\
\hline Air Putih & $\begin{array}{l}\text { Benda cair yang tidak memiliki rasa (tawar) ,tidak berbau, dan } \\
\text { tidak berwarna. }\end{array}$ \\
\hline Dupi & $\begin{array}{l}\text { Nama makanan khas Sunda yang terbuat dari beras ketan yang } \\
\text { dibungkus dengan daun bambu dan dibentuk seperti segitiga. }\end{array}$ \\
\hline Leupeut & $\begin{array}{l}\text { Makanan yang terbuat dari beras ketan yang dibungkus dengan } \\
\text { daun pisang dibentuk persegi panjang dan diikat. }\end{array}$ \\
\hline Bugis & $\begin{array}{l}\text { Makanan manis yang terbuat dari beras ketan yang dihaluskan dan } \\
\text { diisi gula dicampur parutan kelapa di dalamnya, dibungkus } \\
\text { dengan daun pisang dan dilipat kedua ujungnya sehingga } \\
\text { membentuk enam sudut. }\end{array}$ \\
\hline
\end{tabular}


Tabel 4

Makna Konotasi Tradisi Rebo Kasan

\begin{tabular}{cl}
\hline Penanda & \multicolumn{1}{c}{ Petanda } \\
\hline Rebo Kasan & Bersedekah (saling memberi ) \\
Air Putih & Simbol kesucian \\
Dupi & Simbol penolakan yang di dalamnya terdapat rukun agama \\
Leupeut & Simbol memperkuat \\
Bugis & Simbol keyakinan (iman) \\
\hline Sumber: Hasil olahan peneliti
\end{tabular}

Sumber: Hasil olahan peneliti

Tabel 5

Makna Mitos Tradisi Rebo Kasan

\begin{tabular}{cl}
\hline Penanda & \multicolumn{1}{c}{ Petanda } \\
\hline Rebo Kasan & $\begin{array}{l}\text { Setiap makanan dan minuman pemberian pada hari itu dapat } \\
\text { mencegah musibah dan marabahaya. }\end{array}$ \\
Air Putih & $\begin{array}{l}\text { Dapat menghilangkan berbagai kesialan dan menyembuhkan } \\
\text { berbagai penyakit. }\end{array}$ \\
Dupi & Dapat menolak berbagai hal buruk. \\
Leupeut & $\begin{array}{l}\text { Setiap berkumpulnya orang-orang dalam suatu pertemuan yang } \\
\text { baik dapat mempererat persaudaran dengan niat silaturahmi } \\
\text { karena silaturahmi dapat memberikan umur panjang. }\end{array}$ \\
& $\begin{array}{l}\text { Bahwa dalam setiap tindakan atau hal yang berkaitan dengan hal- } \\
\text { hal religi tidak boleh terlepas dari keyakinan kepada Allah SWT } \\
\text { dan hal lainnya yang tertera dalam rukun iman, karena setiap hal } \\
\text { yang dilandasi atas dasar keimanan maka akan berbuah manis atau } \\
\text { baik }\end{array}$ \\
\hline
\end{tabular}

Sumber: Hasil olahan peneliti

Tradisi Rebo Kasan

Sebagai Komunikasi Ritual

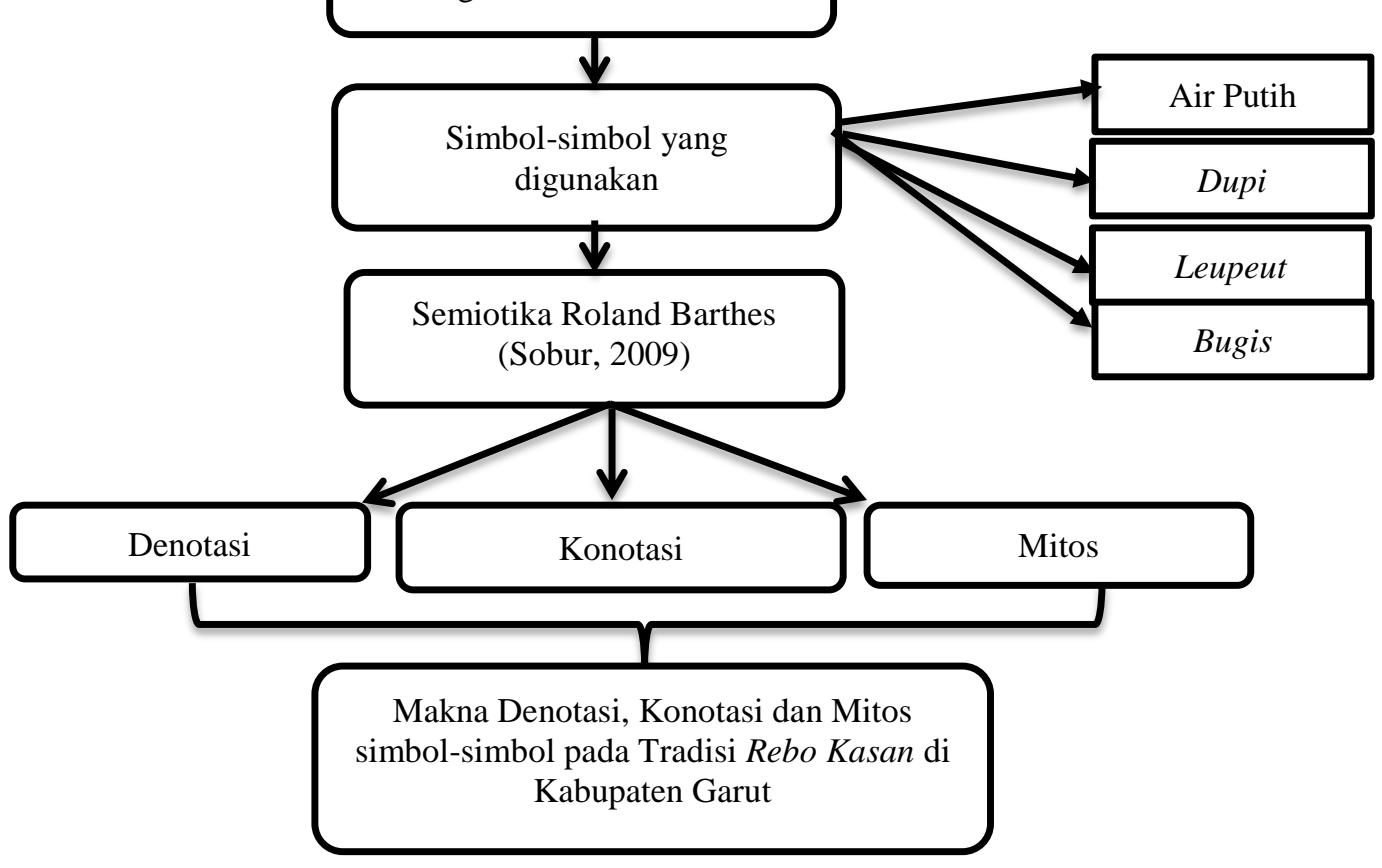

Gambar 1. Kerangka Konseptual 
Rebo Kasan yang mempunyai makna filosofis terkait dengan tataran makna konotasi dalam tataran pemaknaan Roland Barthes. Pemaknaan Rolands Barthes ini memiliki keterkaitan dengan unsur-unsur yang ada pada makna tradisi Rebo Kasan yaitu adanya simbol-simbol yang memiliki ciri atau kekhasan dalam proses aktivitasnya. Hal ini sesuai dengan pendapat (Sobur, 2013) yang mengatakan bahwa, komusi manusia tidak hanya menggunakan simbol-simbol verbal melainkan juga simbol-simbol non verbal.

Pesan-pesan nonverbal tersebut bukan hanya memperkuat pesan verbal yang disampaikan, terkadang malah menyampaikan pesan tersendiri. Oleh karena itu, diperlukan keterampilan untuk menafsirkan dan memahami pesan-pesan nonverbal tersebut. Sama halnya dengan bahasa verbal, pesan-pesan nonverbal pun terikat pada lingkungan budaya tempat komunikasi berlangsung seperti yang tampak pada makna tradisi Rebo Kasan.

Berbagai simbol tradisi Rebo Kasan yang digunakan sesuai dengan ajaran dari nenek moyang daerah di mana tempat tradisi tersebut lahir dan berkembang. Seperti halnya simbol pada sebagian masyarakat Garut (Tradisi Rebo Kasan), belum tentu dapat dijumpai pada perayaan tradisi Rebo Kasan di daerah lain. Sehingga hal ini erat kaitannya dengan bagaimana suatu budaya menggunakan dan memaknai simbol tersebut sesuai dengan nilai dan ideologi yang mereka anut yang mendasarkan diri pada konsep teori Rolands Barthes. Jadi simbol di atas tidak bisa dijadikan kajian umum, karena kajian di atas hanya dapat dijumpai pada tradisi Rebo Kasan khusus di Kabupaten Garut saja. Hal ini bisa dijadikan suatu keunikan tersendiri bagi masyarakat Sunda, yang mengindahkan tradisi ini sampai sekarang.

Menurut pernyataan dari informan bahwa simbol-simbol Rebo Kasan yang terdapat di Kabupaten Garut mempunyai makna yang terkandung di dalamnya. Selain makna tradisinya yang memiliki makna filosofis, makanan yang digunakan dalam Rebo Kasan dan kegiatanya pun memiliki makna tersendiri dalam sebuah tradisi khas di Kabupaten Garut. Makanan yang digunakan tersebut ada yang telah ditentukan dan ada yang tidak ditentukan sejak awal dan yang telah ditentukan tidak bisa digantikan dengan makanan lain. Hal itu merupakan penambahan dan kepraktisan yang diberikan. Dalam pelaksanaannya perayaan Rebo Kasan ini dipandu oleh seorang ustaz yang tingkat religi, pengalaman, dan pengetahuannya dalam seluk beluk tradisi tersebut cukup mendalam. Apa yang disampaikan dalam doa yang dilantunkannya berisikan pituahpituah khusus untuk masyarakat agar mereka terhindar dari berbagai marabahaya yang turun pada hari tersebut. Hal ini sesuai dengan pendapat (Mulyana, 2002) yang mengatakan bahwa individu yang melakukan komunikasi ritual menegaskan komitmennya kepada tradisi keluarga, suku, bangsa, ideologi, atau agamanya. Beberapa bentuk komunikasi ritual antara lain, upacara pernikahan, siraman, berdoa (salat, misa, membaca kitab suci), upacara bendera, momen olah raga, dan sebagainya. Sedangkan ritual itu sendiri adalah cara, tanda, simbol, lambang tentang ketuhanan yang dapat membangkitkan kekuatan kepercayaan.

Rebo Kasan ini merupakan istilah perayaan yang dikenal dalam budaya Sunda, namun tidak setiap daerah masih melakukannya. Hal ini, karena berbagai sudut pandang yang tumbuh dan berkembang dalam masyarakat, terutama mengenai ketentuan atau anjuran dalam agama. Sebetulnya menurut pendapat Pian Sopian tradisi ini hanya dilaksanakan oleh orang-orang Nahdiyyin atau umat Islam yang mengacu pada organisasi tertentu yang dikenal di Indonesia dengan organisasi NU (Nahdatul Ulama). Beberapa organisasi Islam di Indonesia banyak yang tidak setuju dengan pelaksanaan tradisi ini, karena dianggap tidak sesuai dengan kaidah agama Islam. Tradisi ini mengalami pro dan kontra dalam masyarakat, banyak yang menolak dan mengecam tradisi ini. Salah 
satunya karena mereka menilai bahwa hadis tentang turunnya beribu-ribu malapetaka di hari Rabu terakhir Bulan Safar itu adalah dhaif atau palsu tidak bisa dibuktikan keshahihan atau kebenarannya, dan ada pula yang memperdebatkan bahwa tradisi ini merupakan suatu perbuatan bidah atau tidak berdasarkan contoh Rasul. Hal ini terjadi karena mereka tidak mengetahui dan memahami makna dari perayaan tradisi Rebo Kasan ini sendiri.

Segala perbedaan tersebut mungkin saja benar, akan tetapi tidaklah salah jika tradisi tersebut dilaksanakan karena motif dari perayaan tersebut baik dan prosesnya pun dilaksanakan berdasarkan kaidah agama Islam tanpa melakukan suatu hal yang sifatnya syirik atau mempersekutukan Allah. Tradisi Rebo Kasan ini merupakan tradisi yang sifatnya positif, yang bersinggungan dengan dua konsep yaitu agama dan budaya. Hal inilah yang kemudian menyebabkan berbagai makna mulai tumbuh dan berkembang mengenai tradisi ini. Tradisi Rebo Kasan bukan suatu keharusan dalam agama, dan pula perayaan keagamaan yang mutlak, tidak seperti perayaan Idul Fitri dan Idul Adha yang biasa umat Islam lakukan, tetapi tradisi ini merupakan hasil pertalian antara agama dan budaya, sehingga tidaklah heran kalau perayaan di tiap daerahnya dilaksanakan dan dimaknai pula dengan cara yang berbeda. Tidak ada kebenaran yang mutlak dalam kebudayaan karena ini bergantung pada nilai-nilai yang dianut masyarakat.

Tradisi Rebo Kasan ini tidak terlepas atau erat kaitannya dengan komunikasi ritual seperti yang dijelaskan oleh (Carey, 2008), yaitu (1) komunikasi ritual dipahami sebagai kegiatan berbagi, berpartisipasi, berkumpul, bertahan dari kepemilikan akan keyakinan yang sama, dalam praktik komunikasi khususnya pada tradisi Rebo Kasan yang dilakukan oleh sebagian masyarakat Garut yang merupakan praktik untuk mempertahankan kearifan lokal yang dilakukan untuk berkumpul, berbagi, dan berpartisipasi dalam perayaan tradisi Rebo Kasan. (2) Merujuk pada (Carey, 2008), proses komunikasi yang terjadi dalam tradisi Rebo Kasan melalui simbol-simbol seperti air putih, dupi, leupeut bukan berpusat pada transfer (pemindahan informasi) mengenai budaya, akan tetapi dengan melantunkan doa-doa sebagai wujud jauh dari marabahaya; (3) pemilihan simbol komunikasi yang unik atau khas merupakan salah satu ciri yang menonjol dalam bentuk perayaan tradisi Rebo Kasan. Simbol komunikasi pada tradisi Rebo Kasan ini, media adalah pesan. Pesan yang disampaikan lebih memiliki makna tersendiri yang diinterpretasikan dari simbol yang digunakan pada tradisi Rebo Kasan.

Dari hasil deskripsi yang telah dipaparkan, maka tradisi Rebo Kasan ini merupakan tradisi yang sifatnya positif, yang bersinggungan dengan dua konsep yaitu agama dan budaya. Hal inilah yang menyebabkan berbagai makna mulai tumbuh dan berkembang mengenai tradisi ini. Hal ini sependapat dengan (Moon, 2012) yang mengatakan bahwa: Aktivitas ritual keagamaan ataupun bagian dari komunikasi ritual adalah untuk menjaga keseimbangan serta hubungan antara manusia dengan penciptanya. Hal ini, merupakan kegiatan yang dipercaya sebagai suatu keharusan yang akan menentukan keberhasilan aktivitas dalam tradisi Rebo Kasan khususnya bagi sebagian masyarakat Garut.

\section{PENUTUP}

\section{Simpulan}

Makna denotasi air putih memiliki makna denotasi yaitu benda cair yang tidak memiliki rasa (tawar), tidak berbau, dan tidak berwarna. Dupi mengandung makna denotasi yaitu nama makanan khas Sunda yang terbuat dari beras ketan yang dibungkus dengan daun bambu dan dibentuk seperti segitiga. Leupeut mengandung makna denotasi yaitu makanan yang terbuat dari beras ketan yang dibungkus dengan daun pisang dibentuk 
persegi panjang dan diikat. Sedangkan bugis mengandung makna denotasi yaitu makanan manis yang terbuat dari beras ketan yang dihaluskan dan diisi gula dicampur parutan kelapa di dalamnya, dibungkus dengan daun pisang dan dilipat kedua ujungnya sehingga membentuk enam sudut.

Makna konotasi air putih yaitu sebagai simbol kesucian, makna konotasi dupi adalah sebagai simbol penolakan yang di dalamnya terdapat rukun agama, makna konotasi leupeut adalah sebagai simbol mempersatukan dan memperkuat dan makna konotasi bugis adalah sebagai simbol keyakinan (iman).

Mitos air putih yaitu dapat menghilangkan berbagai kesialan dan menyembuhkan berbagai penyakit, mitos dupi yaitu dapat menolak berbagai hal buruk, mitos leupeut setiap berkumpulnya orang-orang dalam suatu pertemuan yang baik dapat mempererat persaudaraan dengan niat silaturahmi karena silaturahmi dapat memberikan umur panjang dan mitos bugis adalah bahwa dalam setiap tindakan atau hal yang berkaitan dengan hal-hal religi tidak boleh terlepas dari keyakinan kepada Allah SWT dan hal lainnya yang tertera dalam rukun iman, karena setiap hal yang dilandasi atas dasar keimanan maka akan berbuah manis atau baik.

\section{Saran}

Hasil penelitian ini diharapkan dapat dijadikan bahan rujukan untuk mengembangkan penelitian selanjutnya yang dikolaborasikan dengan disiplin ilmu lain seperti antropologi, sosiologi yang dapat berguna bagi pengembangan ilmu komunikasi.

Diharapkan dilakukan penelitian atau kajian lain terhadap tradisi Rebo Kasan di Kabupaten Garut dengan teori komunikasi yang berbeda, misalnya teori Interaksi Simbolik, Etnografi Komunikasi yang dapat dijadikan sebagai pembanding pada penelitian ini.

\section{DAFTAR PUSTAKA}

Birowo, M.A. (2004) Metode Penelitian Komunikasi, Teori dan Aplikasi. Yogyakarta, Gitanyali.

Budiman, E. (2008) Upacara Adat Nusantara. Bandung, CV. Gaza Publishing.

Carey, J.W. (2008) Communication as Culture, Revised Edition: Essays on Media and Society. [Online]. Amerika Serikat, Pshycology Press. Available from: http://books.google.it/books?id=N2aRA gAAQBAJ.

Hoed, B.H. (2011) Semiotik dan Dinamika Sosial Budaya. Jakarta, Beji Timur.

John Fiske (2010) Cultural and Communication Studies: Sebuah Pengantar Paling Komprehensif. Yogyakarta, Jalasutra.

John Fiske (2004) Cultural and Communication Studies: Sebuah Pengantar Paling Komprehensif. Yogyakarta, Jalasutra.

Kriyantono, R. (2006) Teknik Praktis Riset Komunikasi. Jakarta, Kencana Prenada Media Group.

Kriyantono, R. (2009) Teknik Praktis Riset Komunikasi. Cetakan ke-4, September. Jakarta, Kencana Prenada Media Group.

Kurniawan (2001) Semiologi Roland Barthes. [Online]. Magelang, Indonesia Tera. Available from: doi:10.1017/CBO9781107415324.004.

Moon, W.J. (2012) Rituals and Symbols in Community Development. [Online]. London, sage Publications. Available from: doi: $10.1177 / 009182961204000203$.

Mulyana, D. (2002) Ilmu Komunikasi Suatu Pengantar. Bandung, Remaja Rosdakarya.

Rosidi, Ajip dan Chaedar, A. (2006) Konferensi Internasional Budaya Sunda. Jilid 2. Bandung, Yayasan Kebudayaan Rancage. PT. Kiblat Buku Utama.

Saripudin, A. (2010) Makna Kearipan Lokal Dalam Mempertahankan Jati Diri Bangsa (Dilihat dari sudut pandang Budaya Sunda). Ciamis, PT. Galuh Pratama.

Sobur, A. (2009) Semiotika Komunikasi. 4th edition. Bandung, PT. Remaja Rosdakarya. 
Sobur, A. (2013) Semiotika Komunikasi. Cetakan kelima. Bandung, PT. Remaja Rosdakarya.

Sumardjo, Jakob \& Saini, K.M. (1994) Apresiasi Kesusasteraan. Jakarta, PT Gramedia Pustaka Utama.

Vera, N. (2014) Semiotika Dalam Riset Komunikasi. Bogor, PT. Ghalia Indonesia. 